\title{
The Effect of Board of Directors Characteristics, Audit Committee Characteristics and Executive Committee Characteristics on Firm Performance in Oman: An Empirical Study
}

\author{
Ebrahim Mohammed Al-Matar ${ }^{1,2}$, Abdullah Kaid Al-Swidi ${ }^{2}$ \& Faudziah Hanim Bt Fadzil ${ }^{2}$ \\ ${ }^{1}$ Faculty of Business and Economics, Ammran University, Yemen \\ ${ }^{2}$ Othman Yeop Abdullah Graduate School of Business, University Utara Malaysia, Malaysia \\ Correspondence: Ebrahim Mohammed Al-Matari, Faculty of Business and Economics, Ammran University, \\ Yemen. E-mail: ibrahim_matri@yahoo.com
}

Received: February 2, 2014 Accepted: April 4, 2014 Online Published: May 30, 2014

doi:10.5539/ass.v10n11p149 URL: http://dx.doi.org/10.5539/ass.v10n11p149

\begin{abstract}
This study is an attempt to achieve the main objective by examining the association between the board of director's characteristics, audit committee characteristics and the executive committee characteristics and the performance of the Oman companies. This study used many assumptions to test the relationship between independent variables and dependent variable as discussed in the section explaining the study method. The data comprised of 162 non-financial companies because financial and non-financial companies employ different methods and they have different structures. As this study attempts to bridge the gap in the existing literature by investigating the association between corporate governance mechanisms and firm performance in the emerging market of Oman, it focuses on adding new important variables of corporate governance mechanisms like board change, the role of secretary on the board, the legal counsel and the executive committee characteristics that improve firm performance.

The findings indicated a significantly positive relationship between board size, board meeting, audit committee independence and executive committee independence, and the Tobin's Q. On the other hand, board independence and legal counsel are significantly and negatively related to Tobin`s Q. Moreover, a positive but insignificant relationship is found between CEO tenure, CEO compensation, audit committee size, and the firm performance (Tobin's Q). Furthermore, board change, the role of the secretary on the board, audit committee meeting, executive committee size and executive committee meeting are revealed to have a negative but insignificant association with firm performance (Tobin`s Q). Finally, this study provides recommendations for future research.
\end{abstract}

Keywords: corporate governance, board of director characteristics, audit committee characteristics, executive committee characteristics and Oman

\section{Introduction}

In recent years, the attention in corporate governance has grown exponentially especially with the major corporate collapses such as Commerce Bank (1991), Enron (2001), WorldCom (2002), Tyco (2002), Global Crossing (2002), Adelphia (2002), Arthur Anderson (2001), Lehman Brothers (2008), Freddy Mac (2008), Fanny Mae (2008), Goldman Sachs (2007), Marconi (2005), Northern Rock (2007), HIH (2001), Harris Scarfe (2001), One. Tel (2001), Parmalat and Yukos in the US, European and others (Jackling \& Johl, 2009; Obiyo \& Lenee, 2011; Ii, Kankpang \& Okonkwo, 2012). In the same context of financial crisis, the capital market in the Sultanate of Oman has also experienced its share of corporate troubles affecting not only large Omani companies such as National Rice Mills SADGI and Omani National Investment Company Holding SAOG, but other several smaller companies which had to ask for assistance from the government. Chargers have been cited over the years revealing that companies "hide information and possess ineffective internal controls and negligent, incompetent and bungling boards of directors. In some instances, there have been claims of fraud on the part of directors. Mismanagement of companies and lack-lustre board of directors are to blame for the sharp drop in share prices that occurred in 1998 and the ensuing loss of investor confidence. All of which underscore the need for higher corporate governance standards (Dry, 2003). 
The concept of corporate governance focuses on the regulation of relationships between the members of the board of directors of the company and its shareholders, employees and regulators from inside or outside the company, and to determine how that must be followed in the interaction between all these parties in overseeing the company's operations. Moreover, the roots of corporate governance to Berle and Means (1932), emanate first from promises to address the issue of the separation of ownership from management. In the light of agency theory, the separation of two positions in the company can enhance the performance of a firm and increase the wealth of shareholders (Jensen \& Meckling, 1976). From other perspective of resource dependence theory; the separation of two positions in the company may not assist to improve the value of the shareholders (Pfeffer \& Slanick, 1979).

The corporate governance mechanisms are to bridge the gap that can occur between managers and owners of the company as a result of the negative practices that could harm the company (Abu Atta, 2003). Besides, the term corporate governance was first used at the beginning of the nineties of the last century. However, its usage has started gaining momentum in recent years and becoming the common language of experts working in international, regional and local organizations (Solomon, 2004). Therefore, the concept of corporate governance emerged to regulate relations among the board of directors, the executive branch managers and audit committees as well as the shareholders and stakeholders in the companies. Ultimately, the issue of corporate governance is now the core of the agency for business leaders and regulators worldwide particularly following the global financial crisis. The crisis has led to many instances of collapse of corporate governance and thus, international regulators are expending efforts to influence suitable regulatory controls. This clarifies the invaluable role of effective corporate governance in the whole society (Ibrahim, Rehman \& Raoof, 2010).

This study is motivated to examine this relation on Oman for many noteworthy reasons. Firstly, studies concerning corporate governance in GCC are still limited such as Al-Hussain and Johnson (2009) in Saudi Arabia, Aljifri and Moustafa (2007) in UAE, Al-Matari et al. (2012) in Saudia Arabia, Al-Matari et al. (2012) in Kuwait, Ghabayen (2012) in Saudia Arabia and Najjar (2012) in Bahrain. However in Oman the relationship between corporate governance and firm performance has been greatly neglected in the past literature. Furthermore, scholarly literature on the relationship between board of directors, audit committee characteristics, executive committee characteristics, the legal counsel, the board change, role of secretary and their effects on firm performance is still lacking. Secondly, Oman is the first GCC country to implement code of corporate governance (Hawkamah on CG Codes of the GCC). This justifies the selection of such a country in the investigation of relationship between corporate governance and firm performance. Lastly, Oman is the first country in the GCC to apply the code of corporate governance that it has implemented in 2002. Moreover, it is the only country in GCC that is not a member of OPEC. This reason is to give the boost to country's economic policies at any time. Therefore, this study attempted to investigate the relationship between corporate governance dimension as mentioned above and their effects on the performance of public listed companies in Oman.

\section{Literature Review and Hypotheses Development}

\subsection{Board of Directors Characteristics and Firm Performance}

\subsubsection{Board Size and Firm Performance}

The board size influences its monitoring ability where the larger its size, the more capable it will be able to monitor top management (Abdullah, 2004). The board size represents the number of directors in position in the corporate board. The board of directors is basically viewed as the main corporate governance mechanism and the primary means for shareholders to indirectly oversee management activities (John \& Senbet, 1998).

Along the same line, Jensen (1993) and Lipton and Lorsch (1992) also revealed that large boards are not as effective as smaller ones and there is a possibility that the members' discussions are not as meaningful as expected. Increase in board size corresponds to difficulties arising in coordination and processing of issues. Shaver (2005) mirrors the same statement by saying that larger board primarily shows issues of responsibility diffusion leading to social loafing and urging the fractionalization of the group and the reduction of the members' commitment to strategic change.

Moreover, larger boards are inefficient in terms of higher spending on the maintenance and report more difficulties in terms of planning, work coordination, decision making and having regular meetings because of the number of members. On the other hand, smaller boards are ideally able to avoid free riding by directors and encourage efficient decision making process. Also, the bigger the board, the more possibility that the stakeholders' interests are considered and the less likely that decisions will be reached in favour of only a few members (Shao, 2010). According to Pfeffer and Salancik (1978), larger boards are more able to obtain invaluable resources including budgeting, funding and leveraging the external environments which can lead to 
the improvement of the performance of the firm.

Despite the empirical evidences regarding the impact of board size on firm performance, the findings are still inconclusive. Prior studies conducted in the developed countries showed consistency of results with the agency theory and confirm a negative association between board size and firm performance. These studies include Florackis (2005), Irina and Nadezhda (2009), Nanka-Bruce (2011) and O'Connell and Cramer (2010). Similarly, in the developing countries many studies found the relationship between the board size and firm performance to be negative (Al Manaseer et al., 2012; Garg, 2007; Kota \& Tomar, 2010; Lin, 2011; MoIlah \& Talukdar, 2007; NoorAfza \& Ayoib, 2009).

According to the resource dependence theory, several studies in the context of the developed countries reported positive relationship between board size and firm performance (e.g. Khanchel, 2007; Larmou \& Vafeas, 2010; Premuroso \& Bhattacharya, 2007; Sueyoshi et al., 2010). In the same line of similar outcome but different countries, a positive relationship has been found between board size and firm performance in the developing countries; this is evidenced in studies conducted by Kang and Kim (2011), Khan and Javid (2011, Kyereboah-Coleman (2007), Kyereboah-Coleman and Biekpe (2006), Ll, Kankpang and Okonkwo (2012), Najjar (2012), Obiyo and Lenee (2011), Swamy (2011), Uadiale (2010) and Yasser, Entebang and Mansor (2011). Apart from agency and resource dependence theory, other evidence has revealed that no association exists between firm performance and board size in the developed nations (Shao, 2010; Siala et al., 2009; Wei, 2007) and the developing countries (Abdurrouf, 2011; Bektas \& Kaymak, 2009; Chiang \& Lin, 2011; Dar et al., 2011; Haslindar \& Fazilah, 2011; Ibrahim et al., 2010; Kajola, 2008; Kula, 2005). On the basis of the previous discussion and supporting arguments, the following hypothesis is developed;

\section{$H_{1}$ : There is a relationship between board size and Tobin`s $Q$.}

\subsubsection{Board Composition and Firm Performance}

Composition of the board is also a measure of the quality of board characteristics that has caught the researchers and practitioners' attention. The board composition is defined as the proportion of independent non-executive members in the board to the total number of members (Lawal, 2012; Uadiale, 2010). According to Fama and Jensen (1983), external directors are more conscientious about their reputations and social status which propel them to oversee management and guarantee the company's effective running. Furthermore, the board composition also assists in reducing agency problem and this is the reason why shareholders often try to replace inside directors with external ones for better management monitoring (Hermalin \&Weisbach, 1991; Weisbach, 1988). Daily (1995) also suggests that external directors are more capable of providing a superior level of objectivity when assessing the situation of the firm - a contention supported by Coughlan and Schmidt (1985) who states that external directors are more superior monitors and are considered as an invaluable disciplining mechanism for managers.

It is further argued that board having more independent directors may minimize management opportunistic behaviour and in essence, safeguard the interests of shareholders more effectively as compared to their dependent counterparts (Masood, 2011; Zubaidah et al., 2009). Generally, all CG practices around the world suggest that an independent member should be included on the board (Nuryanah \& Islam, 2011). Independent directors can minimize the agency cost as it makes the monitoring role and the strategic planning role of the board more effective (Berle \& Means, 1932).

On the basis of agency theory and resource dependence theory, the association between board independence and firm performance is considered to be positive. Several studies have generally reported a positive effect of board composition upon performance in developed countries like Nanka-Bruce (2011), O'Connell and Cramer (2010), Saibaba and Ansari (2011) and Shan and McIver (2011). Also, many researchers in the developing countries have been getting a positive relationship between the board independence and firm performance (Hasnah, 2009; Hsu \& Petchsakulwong, 2010; Kang \& Kim, 2011; Khan et al., 2011; Ll et al., 2012; Nuryanah \& Islam, 2011; Obiyo \& Lenee, 2011; Swamy, 2011; Uadiale, 2010; Yasser et al., 2011).

Form other side, many researchers have also found that there is a negative relationship between board independence and firm performance in developed countries like Singh \& Gaur, 2009; Stanwick \& Stanwick, 2010; Switzer \& Tangb, 2009; Valenti et al., 2011; Wang \& Oliver, 2009). A similar finding is reported in the developing countries in the studies Mohd (2011) and Khan and Javid (2011). Finally, the relationship between board composition and firm performance was found to be non-significant between board independent and firm performance in both the developed states (Hu et al., 2010; Siala et al., 2009; Wei, 2007 \& Yue et al., 2008) and in the developing countries (Al-Matari et al., 2012; Chowdhury 2010; Chugh et al., 2011; Haslindar \& Fazilah 2011; Ibrahim et al., 2010; Prabowo \& Simpson, 2011; Rachdi \& Ameur, 2011). Based on the theoretical perspective 
and debate above, the following hypothesis is expressed:

\section{$\mathrm{H}_{2}$ : There is a positive relationship between board composition and Tobin`s $Q$.}

\subsubsection{Board Meeting and Firm Performance}

Board meeting is the number of meetings that the board holds in a year. According to the Omani code of corporate governance, the board is mandated to hold 4 meetings yearly with a maximum gap of 4 months between two consecutive meetings. Prior studies concentrated on two factors of board characteristics namely size of the board and board independence. The present research adds board meeting to these characteristics (Al Manaseer et al., 2012; Kang \& Kim, 2011; Li et al., 2012; Nanka-Bruce, 2011; Obiyo \& Lenee, 2011).

The board effectiveness depends on the frequency of its meetings as this can enhance the performance of the firm given the fact that the board is provided with more opportunity of monitoring and reviewing the performance of management (Hsu \& Petchsakulwong, 2010). This is consistent with Evans et al., (2002) and Hsu and Petchsakulwong's (2010) findings that revealed that board of directors often increase the frequency of its meetings in order to find solutions to problems concerning declining firm performance. Furthermore, Vafeas (2000) stated that frequency of board meetings is a significant activity because as the board meetings increase in frequency, the more the firm will improve its operating performance. Thus, boards should be inclined to increase frequency of meetings if the situation calls for high control and oversight (Khanchel, 2007; Shivdasani \& Zenner, 2002).

On the other hand, it was argued by Jensen (1993) that daily tasks are what constitutes most of the board's meeting time and hence this limits the chances for external directors to conduct a meaningful oversight over management. Jensen (1993) suggested that boards should not be as active as board activity represents a reaction to adverse performance. In additional to that, Jackling and Johl (2009) revealed that boards' reaction to poor performance by increasing the activity of the board which in turn related with enhanced operating performance in the coming years as this indicates a lag effect. Rebeiz \& Salame (2006) also emphasized on the quality of the board meeting as opposed to frequency. Owing to the significance of the board effectiveness to the firm performance, variation studies were carried out to examine this relationship in the context of developed countries. The association between board meetings and performance of the firm was reported to be positive in such context (Khanchel, 2007; Lin, Ma and Su, 2002) (Khanchel, 2007; Lin, Ma \& Su, 2002) and in the developing states such as, Hasnah (2009), Hsu and Petchsakulwong (2010), Kang and Kim (2011) and Khan and Javid (2011). While some studies have confirmed the negative effect of the board meeting on firm performance in both developed such as García-Sánchez (2010) and Qinghua et al. (2007) and developing countries (Hasnah, 2009; Mohd, 2011). Some studies found that there is no significant relationship between board meetings and firm performance (Kyereboah-Coleman, 2007; Mohd, 2011). Based on the above discussion, it is reasonable to hypothesize the following hypothesis.

\section{$H_{3}$ : There is a relationship between the number board meeting and Tobin`s $\mathbf{Q}$.}

\subsubsection{CEO Tenure and Firm Performance}

CEO tenure is considered as an important construct for research in the field of organization and executive leadership (Herly \& Sisnuhadi, 2011; Simsek, 2007). Additionally, CEO tenure has often been related to the leadership quality and power (Herly \& Sisnuhadi, 2011; Shen, 2003). The CEO's leadership position has been measured in several studies according to the number of years in this position (Bhagat \& Bolton, 2008; Herly \& Sisnuhadi, 2011; Ozkan, 2011; Roselina, 2009; Simsek, 2007).

On the basis of the resource dependence theory, the longer the tenure of the member, the higher will be his experience and knowledge gained (Pfeffer, 1987). In addition to that, Kyereboah-Coleman (2007) argued that with long CEO tenure in the firm, the incentive is heightened to promote the interest of shareholders owing primarily to the fact that besides job security, the CEO is enabled to witness first hand, the outcome of the taken decisions and hence, has a positive impact on performance. Within the same field, the new CEO divulges extra information to steer clear of the suspicion that he/she is pursuing his/her personal interests. Hence, CEOs may be more inclined to divulge information compared to their long tenured counterparts particularly during low performance (Herly \& Sisnuhadi, 2011).

There are generally only a few studies that investigated the association between CEO tenure and firm performance in the developed countries and reported a positive association (Koufopoulos et al., 2008; Simsek, 2007). Some other studies revealed reported similar results with the developing countries like Al-Matari et al. (2012), Herly and Sisnuhadi (2011) and Kyereboah-Coleman (2007).

According to the agency theory advocates, the relationship between CEO tenure and firm performance is 
negative but only few studies have been carried out to look into this relationship in developed countries. In addition, some authors reported a negative result like Evans et al. (2010), Maury (2006) and Garcia et al. (2006). A similar negative result was revealed between CEO tenure and firm performance by studies dedicated to the developing countries (e.g. Al Farooque et al., 2007; Bektas \& Kaymak, 2009; Herly \& Sisnuhadi, 2011; Jackling \& Johl, 2009; Roselina, 2009; Tsai et al., 2006). On the other hand, other studies reported the absence of a relationship between CEO tenure and firm performance (e.g Bhagat \& Bolton, 2008; Fidrmuc \& Fidrmuc, 2007; Firth et al., 2006; Gibson, 2003; Kyereboah-Coleman, 2007). Therefore, the researcher proposed the following hypothesis for further empirical testing;

\section{$\mathrm{H}_{4}$ : There is a relationship between CEO tenure and Tobin`s $Q$.}

\subsubsection{The CEO Compensation and Firm Performance}

Executive compensation is a topic that has been under debate in the field of corporate finance in the past twenty years. Compensation has its most direct effect on the attraction and retention of CEOs. Mayers and Smith (2010) and Narjess (2011) suggested that the compensation can align the interests of managers and shareholders. Previous studies have different measure of CEO compensation such as total salary, bonuses, perquisites, stock option. Compensation in the form of cash encompasses salaries, bonuses and perquisites and stock options but the report on stock options is mixed (for firms that have options) and thus, a consistent measure throughout the firms is challenging to create.

From another perspective, according to Lazear and Rosen (1981), the tournament theory considers executive advancement in the business hierarchy as a tournament where individuals compete for rewards and promotions. Executives who show high performance receive prizes in the form of generous pay and new position perks as the theory postulates that higher rewards can provide a significant success symbol (Lawler, 1981) and works as attraction and motivation towards a group of executives by engaging them in an intra-firm tournament where the grand prize is the CEO position (Lazear \& Rosen, 1981; Main et al., 1993). It has been comprehensively explained in the literature that CEO compensation has a significant impact on the firm performance. A thorough review of the current literature reveals conflicting results regarding this relationship (Adjaoud et al., 2007; Bauer et al., 2009; Deutsch, 2007; Herrmann et al., 2010; Junarsin, 2011; Kubo \& Saito 2008; Lee et al., 2008; Makri et al., 2006; Pissaris et al., 2010; Schiehll \& Bellavance, 2009; \& Yawson, 2006) found a positive relationship between CEO compensation and firm performance in the developed countries. In the developing countries, many researchers also found a positive association between CEO compensation and firm performance (Al Farooque et al., 2007; Lin, Liao \& Chang, 2011).

On the other hand, there is evidence from the developed countries that revealed a negative relationship between CEO compensation and firm performance (Dey, 2008). Similarly, in the developing countries, Al Farooque et al. (2007) found the relationship to be negative. Apart from that, there are some authors who found no relationship between CEO compensation and firm performance e.g, Adjaoud et al. (2007). Therefore, the following hypothesis is proposed.

\section{$\mathrm{H}_{5}$ : There is a positive relationship between $\mathrm{CEO}$ compensation and Tobin`s $\mathbf{Q}$.}

\subsubsection{Board Change and Firm Performance}

The boards of directors are critical monitoring mechanisms that oversee management performance and protect the interests of shareholders (Fama \& Jensen, 1983). The board change is defined to be the appointment of a new member in the board during a year (Fox \& Opong, 1999).

The objective behind board change is to give a new blood to the board to make them more active to fulfil their tasks. The board members' main target is to achieve the shareholder's target and at the same time to achieve the target of the owners. So, the agency theory postulates that the board is responsible to monitor and improve performance (Fama \& Jensen, 1983). On the other hand, from the perspective of resource dependence theory, variety of members provides multiple knowledge and experience with which to enhance performance (Pfeffer, 1972). Hence, this current study expects board change to improve firm performance. More specifically, no known study has examined this relationship in the developing countries in general, and in Oman in particular. Hence, the present study accounts for two important contributions; first, it examines firm board changes impact upon firm performance in Oman and second, unique to itself, it is the pioneering study to examine the board change-firm performance relationship.

Further examination of this relationship is suggested by some researcher such as Al-Matari et al. (2012). More specifically, they encouraged future researchers to study the effect of some variables such as the board change, the role of secretary on the board and the executive committee on firm performance. From this recommendation; 
the current study will be the first study to examine the association between board change, the role of secretary on the board and the role of the executive committee with firm performance. The study expects board change and the executive committee characteristics to improve performance of companies. On a final note, the significance of board change lies in the fact that it provides new blood of directors having varying experiences and knowledge, points of view and motivation. This study attempts to minimize the gap in literature and tests this variable with firm performance. On the basis of prior argument, and supporting arguments, the researcher proposes the following hypothesis;

\section{$H_{6}$ : There is a relationship between board change and Tobin's $Q$.}

\subsubsection{The Role of Secretary on the Board and Firm Performance}

A company secretary often holds a senior position in the private or public sector or company. In the context of large American and Canadian publicly listed firms, a company secretary is often referred to as a Corporate Secretary or the Secretary. He/she is responsible for the administration of the company specifically when it comes to making sure that the company adheres to the statutory and regulatory requirements and to ensure that the decisions of the board are carried out (general theory). This study expected the role of secretary on the board to contribute to the effective performance of the firm through the organization of the board tasks.

Moreover, the company secretary is the legal representative in the firm documents and it is the secretary's responsibility to make sure that the company and its directors' activities are consistent with the law. The secretary is also responsible for registering and communicating with shareholders, to guarantee just payment of dividends and to maintain the records of the company with the inclusion of the lists of directors and shareholders, and the annual accounts (Murray, 1982). In most developed countries, private companies are often mandated by law to elect one person as the secretary to the company and he/she is usually a senior member of the board. The role of the secretary of the board is to arrange all board activities and to give a clear picture about what they discussed and what they should do. The current study expects the significance of this variable to board structure. The importance of secretary of the board to the firm performance was also suggested by Al-Matari et al. (2012). Based on the theoretical and previous discussion, the following hypothesis is reasonable to be proposed for further empirical investigation.

\section{$\mathbf{H}_{7}$ : There is a relationship between the role of secretary on the board and Tobin`s $\mathbf{Q}$.}

\subsubsection{The Legal Counsel and Firm Performance}

The influence of legal profession upon board structure is still partially ambiguous. Initiatives have been launched for its extensive investigation but questions still prevail of what describes board composition (Rose, 2006). Firms may employ external directors during performance decline for their novel ideals and the knowledge pool or even to indicate that the operations are in the process of improvement (Pearce \& Zahra, 1992). According to Davis and Thompson (1994), the appointment of external directors may also be prompted by the threat of lawsuits. From this point of view, the study considers legal counsel as a variable.

The role of legal counsel in the firm is very essential to mitigate judicial allegations. It is expected to give a firm clear insight into future contracts with investors. It is also expected to solve any problem related to the legal system. The separation of the jobs provides power to make the right decisions and to directly monitor management procedures for a better evaluation of performance (Al Busaidi, 2008). In the light of the resource dependence theory, the external source will give a firm a lot of experience and knowledge to deal with the transaction experienced during the life cycle (Rao et al., 2007). The legal counsel can align the firm with the legal system all the time without any problems. Regarding the Omani code of government, the firm should have legal counsel to revise any transaction according to the legal system. For example, the legal code inside the firm governs the relationship between the firm and investors to solve any local or foreign issues. Additionally, the legal counsel tries to plead for the company's rights to third parties.

Given the importance of legal counsel and the position it occupies in the code of corporate governance, and literature's contention of its neglect, in the present study it is considered as a variable. The role of the legal counsel on the firm performance was suggested to be investigated by Al-Matariet al. (2012). Based on previous argument and supporting ones, the following hypothesis is proposed to be empirically tested;

\section{$\mathbf{H}_{8}$ : There is a relationship between the legal counsel and Tobin`s $\mathbf{Q}$.}

\subsection{Audit Committee Characteristics and Firm Performance}

\subsubsection{Audit Committee Size and Firm Performance}

The size of the audit committee is widely explored as an ACC element. It is gauged through the number of audit 
committee members (Bauer et al., 2009; Hsu \& Petchsakulwong, 2010; Nuryana \& Islam, 2011; Obiyo \& Lenee, 2011).

The agency theory postulates that the management-shareholders conflict frequently results in top management's decision to satisfy their interests as opposed to the shareholders', especially when the management is quite opportunistic (Jensen \& Meckling, 1976). Without effective control procedures, top management has a tendency to go against protecting the shareholders' interests (Fama \& Jensen, 1983). Hence, the audit committee has to be effective and efficient in order to resolve these conflicts (Klein, 2002) and achieve sustainable positive performance (Ainuddin \& Abdullah, 2001; Charan, 1998; Mohd et al., 2009).

Based on the premise of the resource dependence theory, the bigger the size of the audit committee, the better it will mean to the firm performance. On the other hand, a small audit committee lacks the same diversity of skills and knowledge of its large counterpart and hence, is ineffective. An audit committee with an ideal size enables members to employ experience and expertise to satisfy the interests of shareholders (Pearce \& Zahra, 1992; Pfeffer, 1987). Although literature provides an extensive discussion of the audit committee size-firm performance relationship, the results reported are still inconclusive. Agency theory advocates propose that if the committee size is too big, the performance is expected to be poor.

Several researchers investigated the relationship between audit committee size and firm performance in both developed countries (e.g. Bozec, 2005) and developing ones (Al-Matari et al., 2012; Hsua \& Petchsakulwong, 2010; MoIlah \& Talukdar, 2007). These studies reported the negative relationship between the two variables. However, some studies in developed countries reported a positive relationship (e.g. Bauer et al., 2009; Khanchel, 2007; Premuroso \& Bhattacharya, 2007; Reddy et al., 2010) as well as some of those conducted in the developing countries (e.g. Al-Matari et al., 2012; Black \& Kim, 2007; Black et al., 2003; Heenetigala \& Armstrong, 2011; Kyereboah-Coleman, 2007; Obiyo \& Lenee, 2011; Swamy, 2011).

Besides the proponents of the agency theory and resource dependence theory, some other studies reported no relationship between the audit committee and firm performance and these include, Abdurrouf (2011), Ghabayen (2012), Kajola (2008), Kim and Yoon (2007), Kyereboah-Coleman (2007), Mohd (2011), Mohd et al. (2009), Nuryanah and Islam (2011) and Wei (2007). On the basis of these findings regarding the relationship, the researcher formulates the following hypothesis;

\section{$\mathrm{H}_{9}$ : There is a relationship between audit committee size and Tobin`s $\mathbf{Q}$.}

\subsubsection{Audit Committee Independence and Firm Performance}

The independence of audit committee is the second ACC element. The committee must be comprised of at least three directors with $2 / 3 \mathrm{rd}$ of them being none-executive independent directors. The chairman of the committee is chosen from the independent directors approved by the BOD. The composition of audit committee refers to the proportion of non-executive members compared to the executive ones (Kang \& Kim, 2011; Abdullah et al., 2008).

An audit committee that is comprised of more number of non-executive directors is deemed more independent than one that has more executive directors (Mohd et al., 2009). In the same way, external audit committee members have a significant role in ensuring corporate governance practices in auditing process (Swamy, 2011). Moreover, according to Abdullah et al. (2008), firms having a majority of internal directors and lacking audit committee are more likely to take part in committing financial fraud compared to their controlled counterparts in a similar industry and with the same size.

Both agency theory and resource dependence theory postulate that autonomy helps in reaching the right decision without barriers and the determination of errors because of the independence of reviewers. The audit committee independence-firm performance relationship is expected to be positive. Nevertheless, only few studies that investigated this relation in developed countries (Dey, 2008; Khanchel, 2007) and developing countries (Abdullah et al., 2008; Nuryanah \& Islam, 2011; Saibab \& Ansari, 2011; Swamy, 2011; Yasser et al., 2011) found a positive result.

On the other hand, some researchers found a negative relationship between audit committee and firm performance in developing nations (Dar et al., 2011) while others found no association between the two (e.g. Al-Matari et al. (2012), Al-Matari et al. (2012), Dar et al. (2011), Ghabayen (2012), Khan and Javid (2011), Kota and Tomar (2010), Kyereboah-Coleman (2007) and Mohd et al. (2009). Based on the above arguments, the researcher proposes the following hypothesis;

$H_{10}$ : There is a positive relationship between audit committee independence and Tobin`s $Q$. 


\subsubsection{Audit Committee Meeting and Firm Performance}

The frequency of audit committee meeting is also one of the most extensively examined ACC as previous studies make use of it as a proxy for audit committee activeness (e.g. Hsu \& Petchsakulwong, 2010; Khanchel, 2007; Kyereboah-Coleman, 2007; Mohd et al., 2009).

Abbott, Peters and Raghunandan (2003) stated that frequent meetings of audit committee may lead to the improvement of the financial accounting processes which in turn, leads to superior performance. Sharing the same perspective is the resource dependence theory that stated that the board meeting helps the board to valuate and pursue a board business from time to time and to solve any problem encountered by employees (Pearce \& Zahra, 1992; Pfeffer, 1987).

From the agency theory's perspective, Jensen (1993) stated that boards have to be relatively relaxed as evidence of higher board activity is a sign of poor performance. Some authors like Jackling and Johl (2009) and Lipton and Lorsch (1992) contended that frequent meetings are likely to lead to higher performance while Rebeiz and Salame (2006) highlighted that the quality of the meeting and not just the quantity is significant for firm performance.

A review of literature revealed no evident relationship between board meeting and firm performance. While some authors revealed a positive relationship between the two variables in developed countries (Khanchel, 2007) and in developing countries (e.g. Kang \& Kim, 2011; Kyereboah-Coleman, 2007), others found a negative relationship (e.g. Petchsakulwong, 2010).

Some other authors found no relationship between audit committee meeting and performance such as Al-Matari et al. (2012), Al-Matari et al. (2012), Kyereboah-Coleman (2007), Mohd (2011) and Mohd et al. (2009). Due to this conflict, no conclusive evidence has been reached. Therefore, this research proposes the following hypothesis;

\section{$H_{11}$ : There is a relationship between audit committee meeting and Tobin`s $Q$.}

\subsection{The Executive Committee Characteristics and Firm Performance}

A monumental lesson has been learned by global commercial entities due to the recent global financial crises and most of them that are affected by these crises have already employed suitable strategies for risk management. Hence, risk management has become one of the most crucial elements of the generation of revenue and maximization of shareholders' value while ensuring the economic stability of the host country (Al-Rashidi, 2010).

In addition, corporate governance is beginning to view risk management seriously as a concept. In support of the risk-based approach, a board using firm-wide risk management system maximizes the firm's risk awareness and in turn, firm knowledge, which would allow the board to achieve meaningful decisions and to contribute to positive governance structures and firm environment. Effective corporate governance has also transformed simple command-and-control statements into consistent and proactive processes that determine, measure, and manages risk throughout firm units (Al-Rimawi, 2001).

Therefore, in support of Al-Matari et al.'s (2012) and Yatim's (2010) statements, this factor should be taken into consideration. The executive committee is one of the crucial factors of internal corporate governance along with committees such as the audit committee and ownership structure. The committees' integration assists in improving the performance of the firm. There is generally lack of studies in literature that is dedicated to the executive committee's relation with performance. As such, the present study concentrates on the executive committee size, independence and meeting, which are explained in detail in the next sections.

\subsubsection{The Executive Committee Size and Firm Performance}

Studies dedicated to the RCC-firm performance relationship are limited and hence the hypothesis of this variable is developed on the basis of studies concerning board size. The first executive committee characteristic is its size - the size of the committee is measured by the number of its members.

According to the agency theory, more number of members on the committee minimizes its effectiveness as the members would spend more time reaching decisions. Jensen and Meckling (1976) contended that the big size of the committee spreads the members' perspectives. In the same context, Shaver (2005) added that larger boards are characterized by responsibility diffusion, which leads to social loafing, and encourages group fractionalization and minimizes the commitment of the group to strategic changes. On the other hand, according to the resource dependence theory, it is the board's responsibility to obtain firm resources through its members' relationship with other firms (Pfeffer, 1972; Provan, 1980; Zald, 1967). The theory proceeds to contend that the 
larger the size of the board, the more competent the corporate governance will be owing to the large pool of skills, knowledge and expertise. In addition, bigger boards are more capable of offering diverse assistance to the firm in light of securing resources and decreasing environmental risks (Goodstein et al., 1994; Nazli Anum, 2010; Pearce \& Zahra, 1992; Pfeffer, 1987).

In sum, common arguments contend that larger board are more diverse and have significant associations to the external environment to assist the firm in obtaining critical resources and ideas for decisions pertaining to corporate policies that are known to improve efficiency (Goodstein et al., 1994; Nanka-Bruce, 2011). Chaganti et al. (1985) and Dalton et al. (1998), revealed that large boards are significant for the experiences contributed by the members to the board discussions and decision making. In short, a larger board is more effective in steering clear of firm failure (Dallas, 2001). Because of the lack of studies examining the relationship between the size of the committee and firm performance in terms of the agency theory and the resource dependence theory, the researcher proposes the following hypothesis;

\section{$H_{12}$ : There is a relationship between the executive committee size and Tobin`s $Q$.}

\subsubsection{The Executive Committee Independence and Firm Performance}

The independence of the executive committee is measured through the number of its independent members. This variable requires evidence from literature. The independent directors of the board are enabled to freely work and are not under the control or influence of major shareholders, management or other parties. Hence, they have more reasons to question and monitor management in order to prevent fraudulent activities as they lack economic and psychological associations with management (Hsu \& Petchsakulwong, 2010).

In view of the agency theory, Berle and Means (1932) and Fama and Jensen (1983) explained that external boards could support the value of the firm by contributing experience and monitoring services. Along the same line, external directors have a role in safeguarding the interests of the shareholders through monitoring with the help of their expertise developed from their past experiences (Mace, 1986).

Based on the resource dependence theory, the board independence integration hinges on its contribution to the enhancement of firm performance. The board may make use of the members' experience and knowledge to reach the right decision at the right time (Pearce and Zahra, 1992; Pfeffer, 1987). According to the above explanation and evidence, the researcher proposes the following hypothesis;

\section{$H_{13}$ : There is a positive relationship between the executive committee independence and Tobin`s $Q$.}

\subsubsection{The Executive Committee Meeting and Firm Performance}

The executive committee meeting is an important element in determining the executive committee's effectiveness. Its effectiveness also depends upon the frequency of meetings. Regular board meetings may result in the enhancement of the performance of the firm as the board exercises ample management monitoring and reviewing rights (Hsu \& Petchsakulwong, 2010). The effectiveness of the executive committee is measured through the frequency of meetings it holds in a year.

Jackling and Johl (2009) and Lipton and Lorsch (1992) claimed that frequent board meetings lead to better performance. Moreover, Conger et al. (1998) and Kyereboah-Coleman (2007) also suggested that board meeting is an indication of the corporate board's effectiveness. The assumption is that when board directors meet frequently, this will likely lead to an improvement in the firm's performance and the board is likely to be performing their duties according to the interests of the shareholders (Kyereboah-Coleman, 2007). In situations calling for high supervision and control, boards have to be inclined to increase frequency of meetings (Khanchel, 2007; Shivdasani \& Zenner, 2002).

A resource dependency theory aspect that relates with CG and performance is the board activity intensity as signified by the board meetings frequency. According to the theory, board meeting assists the board in the evaluation and pursuit of board business and to resolve issues that may crop up. More importantly, meeting frequency shows that the board is trying to exercise an operating role instead of its appropriate oversight role. This activity is erroneous as the board's function is to govern management and not to manage the firm. Hence, the following hypothesis is proposed;

\section{$\mathrm{H}_{14}$ : There is a relationship between the executive committee meeting and Tobin`s $Q$.}

\section{Research Method and the Study Models}

The current study's sample comprises of 81 non-financial firms for the years 2011 and 2012, and excluded financial firms as they differ in structure, methods and accounting practices from the sample (Barontini \& Caprio, 2006; Bøhren \& Strøm, 2010). Data of the firms is obtained from their annual reports compiled in the Muscat 
Securities Market (MSM) website (2012).

The firm performance was measured by market based measurement, the Tobin's Q. It is a forward looking measurement reflecting the shareholder expectations regarding future performance of the firm, which is based on past or current performance (Ganguli \& Agrawal, 2009; Shan \& McIver, 2011; Wahla et al., 2012). As a traditional measure, Tobin's Q measures the expected firm long-run performance (Bozec, Dia \& Bozec, 2010) as opposed to market value of equity which measures the firm's growth opportunities arising from factors external to managerial decisions and this is exhibited through the company's level (Shan \& McIver, 2011; Demsetz \& Villalonga, 2001).

The 14 corporate governance variables namely, board directors characteristics (board size (BOARDSIZE), board independence (BORADIN), board meeting (BOARDME), CEO Tenure (CEOTENU), CEO compensation (CEOCOM), board change (BOARDCH), role of secretary (SECRETA), legal counsel (LEGALCO)), audit committee characteristics (audit committee size (ACSIZE), audit committee independence (ACINDE) and audit committee meeting (ACMEETIN)), executive committee characteristics (executive committee size (ECSIZE), executive committee independence (ECINDE) and executive committee meeting (ECMEETIN)) and two control variables (LEGALCO), firm size (FIRMSIZE), leverage (LEVERAG) were studied. Table 1 offers variables measurement summary. In sum, the relationship between boards of director's characteristics, audit committee characteristics, executive committee characteristics and two control variables were studied by using the following model:

TOBINSQ $=\alpha 0+\gamma 1 *$ BOARDSIZE $+\gamma 2 *$ BORADIN $+\gamma 3 *$ BOARDME $+\gamma 4 *$ CEOTENU $+\gamma 5 *$ CEOCOM $+\gamma 6 *$ BOARDCH $+\gamma 7^{*}$ SECRETA $+\gamma 8^{*}$ LEGALCO $+\gamma 9 *$ ACSIZE $+\gamma 10^{*}$ ACINDE $+\gamma 11 *$ ACMEETIN $+\gamma 12 *$ RCSIZE $+\gamma 13 *$ RCINDE $+\gamma 14 *$ RCMEETIN $+\gamma 15 *$ FIRMSIZE $+\gamma 16^{*}$ LEVERAG $+\varepsilon$

Table 1. Summary of variables measurement

\begin{tabular}{|c|c|c|}
\hline N0 VARIABLES & ACRONYM & OPERATIONALISATION \\
\hline \multicolumn{3}{|l|}{ Dependent Variables (DV) } \\
\hline $1 \quad$ Tobin`s Q Ratio (\%) & TOBINSQ & $\begin{array}{l}\text { The market value of equity plus the } \\
\text { book value of the debt divided by the } \\
\text { book value of the total assets. }\end{array}$ \\
\hline
\end{tabular}

Independent Variables (IV)

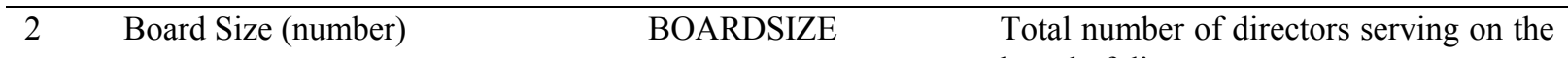

3 Board Composition (\%)

BORADIN

$4 \quad$ Board Meeting (number)

BOARDME

5 CEO Tenure (year)

CEOTENU

6 CEO Compensation (RO)

CEOCOM

7 Board Change

BOARDCH

8 The Secretary on the Board

SECRETA

9 The Legal Counsel

LEGALCO

10 Audit Committee Size (number)

ACSIZE board of directors.

The number of independent non-executive directors on the board relative to the total number of directors.

The frequency number of meetings during a year for the board directors.

The period of CEO's serving in the company.

The total CEO compensation is the sum of the total. Cash compensation that includes salaries, bonuses and perquisites.

Dummy variable I if the board has a new appointment during a year and 0 others.

Dummy variable $I$ if the board has a secretary and 0 others.

Dummy variable $I$ if $I$ if the firm has the legal counsel and 0 others.

Number of members serving on the audit committee. 
11 Audit Committee Independence (\%) ACINDE

12 Audit Committee Meeting (number) ACMEETIN

13 The Executive Committee Size ECSIZE (number)

14 The Executive Committee ECINDE Independence (\%)

15 The Executive Committee Meeting ECMEETIN (number)
Number of non-executive members serving on the audit committee.

The frequency number of meetings during a year for the audit committee.

Total number of members in the executive committee.

The number of independent non-executive directors on the committee relative to the total number of the executive committee.

The frequency number of meetings during a year for the executive committee.

\section{Control Variables (CV)}

\begin{tabular}{llll}
\hline 16 & Firm Size (number) & FIRMSIZE & The natural log of total assets. \\
17 & Leverage $(\%)$ & LEVERAG & $\begin{array}{l}\text { The ratio of total liabilities to total } \\
\text { assets. }\end{array}$
\end{tabular}

\section{Data Analysis and Results}

\subsection{Descriptive Statistic}

The continuous variables' descriptive statistics included the mean, standard deviation, and minimum and maximum, which are obtained with the help of SPSS, version 21.

Table 2. Descriptive statistics of continuous variables

\begin{tabular}{|c|c|c|c|c|c|}
\hline Variables & Unit & Mean & Std. Deviation & Min & Max \\
\hline Board Size (BOARDSIZE) & Number & 7.10 & 1.52 & 5.00 & 12.00 \\
\hline Board independence (BORADIN) & Ratio & 0.88 & 0.19 & 0.00 & 1.00 \\
\hline Board Meeting (BOARDME) & Number & 5.65 & 1.93 & .00 & 15.00 \\
\hline CEO TENURE (CEOTENU) & Years & 10.12 & 2.81 & 3.00 & 20.00 \\
\hline CEO Compensation (CEOCOM) & OR & 56758.31 & 43853.15 & 7785.00 & 239423.00 \\
\hline Audit Committee Size (ACSIZE) & Number & 3.52 & 0.72 & 3.00 & 7.00 \\
\hline $\begin{array}{l}\text { Audit Committee } \text { Independence } \\
\text { (ACINDE) }\end{array}$ & Ratio & 0.93 & 0.19 & 0.00 & 1.00 \\
\hline $\begin{array}{l}\text { Audit Committee } \quad \text { Meeting } \\
\text { (ACMEETIN) }\end{array}$ & Number & 4.74 & 1.28 & 0.00 & 9.00 \\
\hline Executive Committee Size (ECSIZE) & Number & 2.14 & 1.88 & 0.00 & 6.00 \\
\hline $\begin{array}{l}\text { Executive Committee Independence } \\
\text { (ECINDE) }\end{array}$ & Ratio & 0.54 & 0.46 & 0.00 & 1.00 \\
\hline $\begin{array}{l}\text { Executive Committee Meeting } \\
\text { (ECMEETIN) }\end{array}$ & Number & 2.18 & 2.37 & 0.00 & 13.00 \\
\hline FIRM SIZE (FIRMSIZE) & OR & 62979251.03 & 125657047.90 & 605320.00 & 685377000.00 \\
\hline LEVERAGE (LEVERAG) & Ratio & 0.49 & 0.28 & 0.02 & 1.72 \\
\hline Tobin`s Q Ratio (TOBINSQ) & Ratio & 1.23 & 0.59 & 0.27 & 4.13 \\
\hline
\end{tabular}

\subsection{Correlation Analysis}

In this study, the correlation analysis was carried out through the multiple linear regressions. Pallant (2011) 
stated that correlation analysis is useful in describing the strength and direction o of the linear relationship between two variables.

Table 3. Results of Pearson correlation analysis

\begin{tabular}{|c|c|c|c|c|c|c|c|c|c|c|c|c|c|c|}
\hline & 1 & 2 & 3 & 4 & 5 & 6 & 7 & 8 & 9 & 10 & 11 & 12 & 13 & 14 \\
\hline \multicolumn{15}{|l|}{ 1) } \\
\hline \multicolumn{15}{|l|}{ BOARDSIZE } \\
\hline 2) BORADIN & -.038 & & & & & & & & & & & & & \\
\hline 3) & .036 & $.135^{*}$ & & & & & & & & & & & & \\
\hline \multicolumn{15}{|l|}{ BOARDME } \\
\hline 4) & -.063 & $-.162 * *$ & .099 & & & & & & & & & & & \\
\hline \multicolumn{15}{|l|}{ CEOTENU } \\
\hline 5) СЕОСОМ & $.255^{* * *}$ & -.011 & $.130^{*}$ & $.162 * *$ & & & & & & & & & & \\
\hline 6) ACSIZE & $.457^{* * *}$ & $.173 * *$ & .124 & -.127 & $.169 * *$ & & & & & & & & & \\
\hline 7) ACINDE & -.032 & $.741^{* * *}$ & $.173 * *$ & -.103 & .094 & $.137^{*}$ & & & & & & & & \\
\hline 8) & $.151^{*}$ & .107 & $.668^{* * * *}$ & .117 & $.157^{* *}$ & .127 & .112 & & & & & & & \\
\hline \multicolumn{15}{|l|}{ ACMEETIN } \\
\hline 9) RCSIZE & $.343 * * *$ & .112 & $.293 * * *$ & .053 & .122 & $.235^{* * *}$ & .099 & $.242^{* * *}$ & & & & & & \\
\hline 10) RCINDE & $.180 * *$ & $.303 * * *$ & $.223 * * *$ & .042 & .093 & $.182 * *$ & $.224 * * *$ & .122 & $.869^{* * *}$ & & & & & \\
\hline 11) & $.216^{* * *}$ & $.148^{*}$ & $.320 * * *$ & .059 & $.159 * *$ & $.187 * *$ & .110 & $.254 * *$ & $.725^{* * *}$ & $.719 * * *$ & & & & \\
\hline \multicolumn{15}{|l|}{ RCMEETIN } \\
\hline 12) & $.321 * * *$ & -.046 & .070 & .129 & $.583 * * *$ & $.194 * *$ & .020 & $.217^{* * *}$ & .101 & .037 & .100 & & & \\
\hline \multicolumn{15}{|l|}{ FIRMSIZE } \\
\hline 13) & -.088 & -.024 & -.059 & $.134^{*}$ & .032 & -.059 & -.015 & -.028 & $-.145^{*}$ & -.076 & -.122 & -.062 & & \\
\hline \multicolumn{15}{|l|}{ LEVERAG } \\
\hline 14) & $.176^{* *}$ & $-.206 * * *$ & .091 & .075 & $.159 * *$ & .055 & -.003 & -.039 & -.006 & -.025 & -.068 & .071 & -.080 & \\
\hline TOBINSQ & & & & & & & & & & & & & & \\
\hline
\end{tabular}

In measuring the association between all the variables and the Tobin`s $\mathrm{Q}$ as another measure of firm performance, it was found that board size (BOARDSIZE) and CEO compensation (CEOCOM) have a positive significant relation with Tobin's Q at the 0.05 level. In addition, board meeting (BOARDME), CEO tenure (CEOTENU), audit committee size (ACSIZE) and firm size (FIRMSIZE) have a positive relation with Tobin's Q, but it is not significant. On the other hand, board independence (BORADIN) has strong negative relation with Tobin`s $\mathrm{Q}$ at the 0.01 level and audit committee independence (ACINDE), audit committee meeting (ACMEETIN), executive committee size (ECSIZE), executive committee independence (RCINDE), executive committee meeting (ECMEETIN) and leverage (LEVERAG) were found to be negatively but not significantly related with Tobin`s Q.

\subsection{Multiple Liner Regression Analysis}

The regression analysis is one of the most widely used statistical methods in many science disciplines applications (Hair et al., 2010). DeCoster (2004) claimed that a statistical method enables the researcher to predict the value of one variable based on the value of another or more variables. He added that when the regression analysis is run, a regression equation that predicts the dependent variable's value through the independent variables' arises.

\subsection{Companies Profile}

Table 4 , shows the profile of the firms regarding the board change variable, the role of secretary variable and the legal counsel variable 
Table 4. Frequency of the Companies regarding to the board change variable, the role of secretary variable and the legal counsel variable

\begin{tabular}{lll}
\hline & Frequency & Percentage \\
\hline Board Change & 71 & $43.8 \%$ \\
No change & 91 & $56.2 \%$ \\
Total & 162 & $100 \%$ \\
Secretary & 86 & $53.1 \%$ \\
No secretary & 76 & $46.9 \%$ \\
Total & 162 & $100 \%$ \\
Legal & 94 & $58 \%$ \\
No legal & 68 & $42 \%$ \\
Total & 162 & $100 \%$ \\
\hline
\end{tabular}

\subsection{Regression Results of Model (Based on Marketing Measure)}

The finding suggests that larger boards are associated with higher performance. Thus, hypothesis H1b is supported. This finding is consistent with previous studies that found a positive relationship between board size and Tobin's Q either in developed countries such as Khanchel, 2007; Larmou \& Vafeas, 2010; Premuroso \& Bhattacharya, 2007; Sueyoshi et al., 2010 or in developing countries like Kang and Kim (2011), Khan and Javid (2011, Kyereboah-Coleman (2007), Kyereboah-Coleman and Biekpe (2006), Ll, Kankpang and Okonkwo (2012), Najjar (2012), Obiyo and Lenee (2011), Swamy (2011), Uadiale (2010) and Yasser, Entebang and Mansor (2011). One probable clarification for the positive significant association between board size and Tobin`s is that this result is supported by resource dependence theory, which postulates that the board has to be more strict when it comes to monitoring of management to ensure minimal financial fraud.

The result reported a negative significant relation between board independence and Tobin's $Q$ as presented in Table 6, indicating that the higher the board independence, the lower performance of the firm. This is consistent with the results of prior researches that revealed a negative significant association between board independence and Tobin`s Q either in developed countries (Singh \& Gaur, 2009; Stanwick \& Stanwick, 2010; Switzer \& Tangb, 2009; Valenti et al., 2011; Wang \& Oliver, 2009) or in developing countries like Mohd (2011) and Khan and Javid (2011). One reasonable explanation for the negative significant association between board independence and Tobin's is that frequent board meetings do not automatically translate to enhanced firm performance but it may reflect issues in the firm (Jensen, 1993). In addition, Jackling and Johl (2009) contended that increased board activity is a reaction to negative performance, which is in turn, linked to enhanced operating performance in the future. In line with resource dependence theory and the expectation of this study, the result found a positive significant association between board meeting and Tobin`s Q, as apparent in Table 6. This finding suggests that board meeting is associated with higher firm performance. This finding is similar with previous studies that reported a positive significant relationship between board meeting and Tobin's Q whether in developed countries (Khanchel, 2007; Lin, Ma \& Su, 2002) or in developing countries (Hasnah, 2009; Hsu \& Petchsakulwong, 2010; Kang \& Kim, 2011; Khan \& Javid, 2011). One reasonable explanation for positive significant association between board meeting and Tobin`s is that this finding is consistent with the theory of resource dependence that postulates that board meeting helps the board to evaluate and pursue a board business in a timely manner and to solve any problem faced by employees (Pearce \& Zahra, 1992; Pfeffer, 1987). Hence, increased board meetings translate to increased firm performance.

The result as shown in Table 6 found no significant association between CEO tenure and Tobin`s Q. The result of this study is similar with prior studies that found insignificant associations between CEO tenure and Tobin's Q (Bhagat \& Bolton, 2008; Fidrmuc \& Fidrmuc, 2007; Firth et al., 2006; Gibson, 2003; Kyereboah-Coleman, 2007). The possible explanation behind the lack of relationship between CEO tenure and Tobin's $Q$ is that CEOs having longer tenure will decrease disclosures regarding corporate governance practices because they are convinced that they have the authority and they are not effectively monitored by the board of commissioners (Shen, 2003). Moreover, the result found insignificant association between CEO compensation and Tobin`s Q, as apparent in Table 6. Thus, H5b is not supported. This result is alike with prior studies that revealed insignificant association between CEO compensation and Tobin's Q such as Adjaoud et al. (2007). One acceptable 
justification for the insignificant association between CEO compensation and Tobin`s Q is that managers are inclined to time stock-option grants to their benefit, indicating that this device may not be totally effective. As a result, shareholders should opt for the strong link of CEO compensation to firm value as this link is provided by CEO. Therefore, it is necessary to find compensation and rewards for employees within the company to motivate employees to work effectively in a competitive environment within the company itself.

The result of the study also reveals an insignificant association between board change and Tobin's $Q$ as apparent in Table 6. Therefore, hypothesis H6 is not supported. The justification behind the insignificant association between board change and Tobin's Q may be explained by ambiguous insight of the variable in the Omani code. It is hence important that regulators stress on this change every year. Another reason for this insignificant relationship may be ineffective company policy in appointing persons with right education, experience and knowledge. In addition, the result as apparent in Table 6, found no significant association between the role of secretary on the board and Tobin's Q. Thus, hypothesis H7 is not supported. The justification behind the insignificant relationship between secretary of the board's role and Tobin's Q is the lack of the variable's application in all listed companies, which in turn, may have produced poor outcome. Hence, regulators should encourage all listed companies to keep the role of secretary of the board into consideration and to acknowledge its significance.

The outcome found a negative association between the legal counsel and Tobin's Q. Therefore, hypothesis H8 is not supported. This result suggests that legal counsel is associated with low performance of company. The negative significant relationship between the role of legal counsel and Tobin's Q may be attributed to the lack of mention of this variable in the Omani Code of Corporate Governance and the lack of explanation of its importance which will minimize court allegations and provide insurance between future contracts with other companies. This variable works to minimize misunderstanding between a company and others like it. Hence, owing to its novelty as a variable, and the Omani code's overlooking of it, the role of legal counsel is insignificant and negatively related to Tobin's Q. On the contrary, the result found insignificant association between audit committee size and Tobin's Q. Consequently, hypothesis H9 is not supported. The result of this study was similar with those of previous scholars like Abdurrouf (2011), Ghabayen (2012), Kajola (2008), Kim and Yoon (2007), Kyereboah-Coleman (2007), Mohd (2011), Mohd et al. (2009), Nuryanah and Islam (2011) and Wei (2007).A probable reason for the insignificant finding of audit committee size and Tobin's Q is that the firms concentrated on the AC effectiveness as opposed to their sizes as they do not deem AC size to be an important factor in improving the committee's effectiveness. For the effectiveness of AC, it should be made up of independent, expert and well-informed members and should wield sufficient authority (Mohiuddin \& Karbhari, 2010).

The result presented a positively significant association between audit committee independence and Tobin`s Q as apparent in Table 6. Hence, hypothesis H10 is not supported. The result of this variable is similar to previous studies that revealed positive relationship between them whether in developed countries (Dey, 2008; Khanchel, 2007) or developing countries (Abdullah et al., 2008; Nuryanah\& Islam, 2011; Saibaba \& Ansari, 2011; Swamy, 2011; Yasser et al., 2011). One explanation for the positive significant relationship between audit committee independence and Tobin's $\mathrm{Q}$ is that this finding is supported by both agency theory and resource dependence theory where autonomy is given to make the right decision without any restriction or condition, to detect errors and to reveal them without any problems because independent reviewers are not related to the company in any way. On the other hand, the result found no significant association between audit committee meeting and Tobin's Q. Thus, hypothesis H11 is not supported. This result is similar to previous researchers findings like Al-Matari et al. (2012), Al-Matari et al. (2012), Kyereboah-Coleman (2007), Mohd (2011) and Mohd et al. (2009). A possible reason for insignificant finding of audit committee meeting and Tobin`s Q explained by Jackling and Johl (2009) and Lipton and Lorsch (1992) who believed that the more frequent the meetings are, the more likely they will lead to superior performance of the firm. More specifically, frequent meetings every year indicates that the board is playing an operating role as opposed to an oversight role and it is generally believed that the role of the board is to govern management as opposed to manage the firm.

Furthermore, the finding revealed an insignificant link between executive committee size and Tobin`s Q. So, hypothesis H12 is not supported. The insignificant result between the size of executive committee and Tobin's Q may be explained through the fact that executive committees in Oman are not considered as important when compared to other committees. This result indicates that the role of some specific board practices in Oman does not exist. More importantly, the Code of Corporate Governance in Oman largely ignores this variable and its value and hence, the insignificant association. In the same line, the result found no significant association between audit committee meeting and Tobin's $\mathrm{Q}$ as consistent with accounting measurement result. So, 
hypothesis $\mathrm{H} 14$ is not supported. Hence, the executive committee meeting is not related to performance enhancement. One plausible explanation for the insignificant association between executive committee meeting and Tobin's Q is that board meetings are not often useful as the limited time NEDs spent together is not spent on fruitful exchange among themselves and with management. This generally stems from the chief executive officer's setting of meetings.

Finally, the result revealed a positive significant association between executive committee independence and Tobin`s Q. Thus, hypothesis H113 is supported. This study suggested that executive committee independence is associated with higher firm performance. A possible justification behind the positive significant relationship between executive committee independence and Tobin's Q is the support from both agency theory and resource dependence theory where autonomy is provided in order to make the right decision without limitations and to work at highlighting errors as independent reviewers are not linked to the company.

Based on the regression results the model equation is Tobin`s $\mathrm{Q}=0.837+0.093^{*}$ Board Size (BOARDSIZE) 1.397* Board independence (BORADIN) $+0.065^{*}$ Board Meeting (BOARDME) $-0.189^{*}$ Legal Counsel $($ LEGALCO $)-0.936 *$ Audit Committee Independence (ACINDE) $+0.386 *$ Executive Committee Meeting (ECMEETIN).

Table 5. Regression results of model (Dependent= Tobin`s Q)

\begin{tabular}{llll}
\hline Variables & Standardized Coefficients & t-value & Sig. \\
\hline Board Size (BOARDSIZE) & Beta & 2.593 & 0.010 \\
Board independence (BORADIN) & 0.241 & -3.820 & 0.000 \\
Board Meeting (BOARDME) & -0.462 & 2.056 & 0.042 \\
CEO TENURE (CEOTENU) & 0.214 & 0.649 & 0.518 \\
CEO Compensation (CEOCOM) & 0.051 & 1.297 & 0.197 \\
Board Change (BOARDCH) & 0.120 & -0.892 & 0.374 \\
Secretary (SECRETA) & -0.070 & -0.629 & 0.531 \\
Legal Counsel (LEGALCO) & -0.050 & -2.005 & 0.047 \\
Audit Committee Size (ACSIZE) & -0.159 & 0.173 & 0.863 \\
Audit Committee Independence (ACINDE) & 0.015 & 2.749 & 0.007 \\
Audit Committee Meeting (ACMEETIN) & 0.304 & -1.272 & 0.205 \\
Executive Committee Size (ECSIZE) & -0.133 & -1.265 & 0.208 \\
Executive Committee Independence (ECINDE) & -0.229 & 1.667 & 0.098 \\
Executive Committee Meeting (ECMEETIN) & 0.302 & -1.654 & 0.100 \\
FIRM SIZE (FIRMSIZE) & -0.192 & -0.831 & 0.407 \\
LEVERAGE (LEVERAG) & -0.079 & -1.026 & 0.306 \\
\hline $\mathrm{R}^{2}$ & -0.080 & & 0.234 \\
Adjusted R & & & 0.150 \\
F-value & & & 2.771 \\
F-Significant & & & 0.001 \\
Durbin Watson statistics & & 1.833 \\
\hline
\end{tabular}

\section{Conclusion}

This study is considered to have achieved its main target, which is to test the relationship between the corporate governance mechanisms and the company performance among Omani non-financial companies. Moreover, this study added some new variables to the body of knowledge such as, the board change, the role of secretary on the board, the legal counsel and the executive committee characteristics. The present study employed several 
assumptions to examine the association between independent variables and dependent variable as discussed in the research methodology section. The data used for this study comprised of 162 non-financial companies and according to the findings, a significant positive relationship exists between board size, board meeting, audit committee independence and executive committee independence and Tobin's Q. On the other hand, the findings also showed a significant negative association between board independence, legal counsel and Tobin's Q and a positive but insignificant relationship between CEO tenure, CEO compensation, audit committee size and firm performance (Tobin's Q). Finally, a negative but insignificant association was revealed between board change, the secretary's role on the board, audit committee meeting, executive committee size, executive committee meeting, and firm performance (Tobin's Q).

This study has many recommendations for future studies. Firstly, this study examined the direct relationship between corporate governance and firm performance but there is a lack of previous research examining the moderating or mediating effect of other variables on the relation between corporate governance and firm performance such as, board diversity, audit quality, CEO compensation, culture, regulation, Islamic perspective, among others that will lead to help in improving performance. Secondly, this study recommends future research to integrate between board of directors, audit committee, executive committee and ownership structure as this integration may lead to enhancing corporate governance practice. Thirdly, future authors should investigate the relationship between corporate governance and firm performance in-depth, by adding new variables such as the commitment of the board, the attending rewards, the compensation of the board and committee, the risk committee, the remuneration committee, social responsibility corporate and others. Fourthly, this study recommends future authors to study the relationship between corporate governance and firm performance through other theories such as, stewardship theory, institutional theory, stakeholder theory, transaction cost theory, political theory, and ethical theories as these theories may be more suitable for this environment. Finally, future authors should extend proxy of firm performance and integrate between accounting and marketing measurement as this may lead to effective performance in both the short- and long-term. Finally, based on the previous studies, there is a paucity of existing literature that examined the association between corporate governance and firm performance in the emerging countries like Gulf countries.

\section{References}

Abbott, L. J., Parker, S., Peters, G. F., \& Raghunandan, K. (2003). The association between audit committee characteristics and audit fees. Auditing: A Journal of Practice and Theory, 22(2), 17-32.

Abdullah, M. S., Shah, S. Z. A., \& Hassan, A. (2008). Impact of Corporate Governance on Financial Performance of Firms: Evidence from Pakistan. The Business Review, Cambridge, 11, 282-290.

Abdullah, S. N. (2004). Board composition, CEO duality and performance among Malaysian listed companies. Corporate governance, 4(4), 47-61.

Abdurrouf, M. A. (2011). The relationship between corporate governance and value of the firm in developing countries: Evidence from Bangladesh. The International Journal of Applied Economics and Finance, 5(3), 237-244.

Adjaoud, F., Zeghal, D., \& Andaleeb, S. (2007). The Effect of Board's Quality on Performance: A study of Canadian firms. Journal compilation, 15(4), 623-636.

Ainuddin, R. A., \& Abdullah, N. (2001). Board characteristics and corporate governance of public listed companies in Malaysia. Working paper, Universiti Kebangsaan Malaysia, Bangi.

Al Farooque, O. A., Zijl, T. V., Dunstan, K., \& Karim, A. K. M. W. (2007). Corporate Governance in Bangladesh: Link between Ownership and Financial Performance. Corporate Governance, 15(6), 1453-1469.

Al Manaseer, M. F. A., Al-Hindawi, R. M., Al-Dahiyat, M. A., \& Sartawi, I. I. (2012). The Impact of Corporate Governance on the Performance of Jordanian Banks. European Journal of Scientific Research, 67(3), 349-359.

Al Rashid, F., \& Jamal, A. (2010). The importance of corporate governance in the Arab countries. For corporate governance conference in Kuwait.

Al-Hussain, A. H., \& Johnson, R. L. (2009). Relationship between corporate governance efficiency and Saudi Banks' performance. The Business Review, Cambridge, 14(1), 111-117.

Aljifri, K., \& Moustafa, M. (200). The impact of corporate governance mechanisms on the performance of UAE firms: an empirical analysis. Journal of Economic and Administrative Sciences, 23(2), 71-93. 
Al-Matari, E. M., Al-Swidi, A. K., Faudziah, H. B., \& Al-Matari, Y. A. (2012). The Impact of board characteristics on Firm Performance: Evidence from Nonfinancial Listed Companies in Kuwaiti Stock Exchange. International Journal of Accounting and Financial Reporting, 2(2), 310-332.

Al-Matari, Y. A., Al-Swidi, A. K., \& Bt Fadzil, F. H. (2012). Audit committee effectiveness and performance of Saudi Arabia listed companies. Wulfenia Journal, 19(8), 169-188.

Al-Matari, Y. A., Al-Swidi, A. K., Bt Fadzil, F. H., \& Al-Matari, E. M. (2012). Board of directors, audit committee characteristics and performance of Saudi Arabia listed companies. International Review of Management and Marketing, 2(4), 241-251.

Al-Rimawi, L. M. (2001). Jordanian, Kuwaiti and Omani Securities Regulation: Can they be Subject Matter of a Viable Comparative Study with EU Securities Regulation? Journal of Financial Regulation and Compliance, 9(3), 253-273.

Barontini, R., \& Caprio, L. (2006). The effect of family control on firm value and performance: Evidence from continental Europe. European Financial Management, 12(5), 689-723.

Bauer, R., Eichholtz, P., \& Kok, N. (2009). Real estate, corporate governance and performance: The Reit Effect. Financial Management, XX(XX), 1-29.

Bektas, E., \& Kaymak, T. (2009). Governance mechanisms and ownership in an emerging market: The case of Turkish banks. Journal Emerging Markets Finance and Trade, 45(6), 20-32.

Berle, A., \& Means, G. (1932). The Modern Corporation and Private Property. New York, NY: Macmillan.

Bhagat, S., \& Bolton, B. (2008). Corporate governance and firm performance. Journal of corporate finance, 14 , 257-273.

Black, B., \& Kim, W. (2007). The value of board independence in an emerging market: IV, DiD, and Time Series Evidence from Korea. Working Paper. 1-52.

Black, B., Jang, H., \& Kim, W. (2003). Does corporate governance affect firms' market values? Evidence from Korea'. Working paper no. 237, Stanford Law School, Stanford.

Bognanno, M. (2001). Corporate tournaments. Journal Labor Econ, 19, 290-315.

Bøhren, Ø., \& Strøm, R. Ø. (2010). Governance and Politics: Regulating Independence and Diversity in the Board Room. Journal of Business Finance \& Accounting, 37(9), 1281-1308. http://dx.doi.org/10.1111/j.1468-5957.2010.02222.x

Bozec, R. (2005). Boards of directors, Market discipline and Firm Performance. Journal of Business Accounting, 32(9\&10), 1921-1960.

Bozec, R., Dia, M., \& Bozec, Y. (2010). Governance - performance relationship: A Re-examination using technical efficiency measures. British Journal of Management, 21, 684-700. http://dx.doi.org/10.1111/j.1467-8551.2008.00624.x

Chaganti, R. S., Mahajan, V., \& Sharma, S. (1985). Corporate board size, composition and corporate failures in retailing industry. Journal of Management Studies, 22(4), 400-417.

Charan, R. (1998). How corporate boards create competitive advantage. Jossey-Bass, San Francisco, CA.

Chiang, H., \& Lin, M. (2011). Examining board composition and firm performance. The International Journal of Business and Finance Research, 5(3), 15-28.

Chowdhury, K. (2010). Board composition and firm performance: Evidence from Bangladesh. A Sceptical View, 4(3), 103-110.

Chugh, L. C., Meador, J. W., \& Kumar, A. S. (2011). Corporate governance and firm performance: Evidence from India. Journal of Finance and Accounting, 7, 1-10.

Cohen, J. (1988). Statistical power analysis for the behavioral sciences (2nd ed.). New Jersey: Lawrence Erlbaum Associates.

Coughlan, A., \& Schmidt, R. (1985). Executive compensation, management turnover, and firm performance: an empirical investigation. Journal of Accounting and Economics, 7, 43-66.

Daily, C. M. (1995). The relationship between board composition and leadership structure and bankruptcy reorganization outcomes. Journal of Management, 21(6), 1041-1056.

Dallas, L. L. (2001). Developments in U.S. boards of directors and the multiple roles of corporate boards. 
Working Paper, University of San Diego.

Dalton, D. R., Daily, C. M., Ellstrand, A. E., \& Johnson, J. L. (1998). Meta-analytic reviews of board composition, leadership structure and financial performance. Strategic Management Journal, 19, 269-290. http://dx.doi.org/10.1002/(SICI)1097-0266(199803)19:3<269::AID-SMJ950>3.0.CO;2-K

Dar, L. A., Naseem, M. A., Rehman, R. U., \& Niazi, G. S. (2011). Corporate Governance and Firm Performance a Case Study ofPakistan Oil and Gas Companies Listed in Karachi Stock Exchange. Global Journal of Management and Business Research, 11(8), 1-10.

Demsetz, H., \& Villalonga, B. (2001). Ownership structure and corporate performance. Journal of Corporate Finance, 7, 209-233.

Deutsch, Y. (2007). The influence of outside directors 'stock-option compensation on firms' R \& D. Corporate Governance journal, 15(5), 816-828.

Dry, E. K. (2003). Corporate governance in the Sultanate of Oman. Global Law Bus, 3, 45-82.

Evans, J. H., Nagarajan, N. J., \& Schloetzer, J. D. (2010). CEO Turnover and retention light: Retaining former CEOs on the board. Journal of Accounting Research, 48(5), 1015-1047. http://dx.doi.org/10.1111/j.1475-679X.2010.00383.x

Evans, J., Evans, R., \& Loh, S. (2002). Corporate governance and declining firm performance. International Journal of Business Studies, 10(1), 1-18.

Fama, E. F. (1980). Agency problems and the theory of the firm. Journal of Political Economy, 88, 288-307. http://dx.doi.org/10.1086/260866

Fama, E. F., \& Jensen, M. C. (1983). Separation of ownership and control. Journal of Law and Economics, 26, 301-325. http://dx.doi.org/10.1086/467037

Fama, E., \& Jensen, M. (1983). Agency problems and residual claims. The Journal of Law and Economics, 26(2), 327-349.

Fidrmuc, J. P., \& Fidrmuc, J. (2007). Fire the manager to improve performance? Economics of Transition, 15(3), 505-533.

Firth, M., Fung, P. M. Y., \& Rui, O. M. (2006). Firm performance, governance structure, and top management turnover in a transitional economy. Journal of Management Studies, 43(xxx), 1289-1330. http://dx.doi.org/10.1111/j.1467-6486.2006.00621.x

Florackis, C. (2005). Internal corporate governance mechanisms and corporate performance: evidence for UK firms. Journal of Applied Financial Economics Letters, 1(4), 211-216. http://dx.doi.org/10.1080/17446540500143897

Fox, A. F., \& Opong, K. K. (1999). The impact of board changes on shareholders wealth: Some UK evidence. Corporate Governance, an International Review, 7(4).

Ganguli, S. K., \& Agrawal, S. (2009). Ownership structure and firm performance: An empirical study on listed mid-cap Indian companies. The IUP Journal of Applied Finance, 15(12), 37-52.

Garcia, R., González, M., \& Ortega, C. (2006). The Impact of CEO and director turnover on financial performance in Venezuela. Latin American Business Review, 7(2), 1-18. http://dx.doi.org/10.1300/J140v07n02

García-Sánchez, I.-M. (2010). The effectiveness of corporate governance: Board structure and business technical efficiency in Spain. CEJOR, 18, 311-339. http://dx.doi.org/10.1007/s10100-009-0112-4

Garg, A. K. (2007). Influence of board size and independence on firm performance: a study of Indian companies. VIKALPA, 32(3), 39-61.

Ghabayen, M. (2012). Board characteristics and firm performance: Case of Saudi Arabia. International Journal of Accounting and Financial Reporting, 2(2), 168-200.

Gibson, M. (2003). Is Corporate Governance Ineffective Emerging Markets? Journal of Financial Quantitative Analysis, 38(1), 231-250.

Goodstein, J., Gautam, K., \& Boeker, W. (1994). The effects of board size and diversity on strategic change. Strategic Management Journal, 15, 241-250.

GulfBase. (2013). GCC Stock Markets - Markets Summary. Retrieved from http://www.gulfbase.com/ 
Hair, J. F., Anderson, R. E., Tatham, R. L., \& Black, W. C. (2010). Multivariate data analysis (2nd ed.). New York: Prentice-Hall, Upper Saddle River, NJ.

Hamid, A. B. (2008). Oman's Experience in issuing and implementation of the Code of Corporate Governance. Working Paper to Corporate Governance Congress organized by JJLK Middle East Dubai 30th March 2008.

Haslindar, I., \& Fazilah, A. (2011). Corporate governance mechanisms and performance of public family-ownership in Malaysia. International Journal of Economics and Finance, 3(1), 105-115.

Hasnah, K. (2009). The impact of corporate governance and board performance on the perfprmance of public listed companies in Malaysia. Ph.D Dissertation, University Sains Malaysia.

Heenetigala, K., \& Armstrong, A. (2011). The impact of corporate governance on firm performance in an unstable economic and political environment: Evidence from Sri Lanka. Conference on financial markets and corporate governance, 13, 1-17.

Herly, M., \& Sisnuhadi. (2011). Corporate governance and firm performance in Indonesia. International Journal of Governance, 1(1), 1-20.

Hermalin, B., \& Weisbach, M. (1991). The effects of board composition and direct incentives on firm performance. Financial Management, 20, 101-112.

Herrmann, P., Kaufmann, J., \& Auken, H. V. (2010). The role of corporate governance in R \& D intensity of US-based international firms. International Journal of Commerce and Management, 20(2), 91-108. http://dx.doi.org/10.1108/10569211011057236

Hsu, W., \& Petchsakulwong, P. (2010). The impact of corporate governance on the efficiency performance of the thai non-life insurance industry. The Geneva Papers on Risk and Insurance Issues and Practice, 35(1), S28-S49. http://dx.doi.org/10.1057/gpp.2010.30

Hu, H. W., Tam, O. K., \& Tan, M. G. (2010). Internal governance mechanisms and firm performance in China. Asia Pacific Journal of Management, 27, 727-749. http://dx.doi.org/10.1007/s10490-009-9135-6

Ibrahim, H., \& AbdulSamed, F. A. (2011). Agency costs, corporate governance mechanisms and performance of public listed family firms in Malaysia. South African Journal of Business Management, 42(3), 17-26.

Ibrahim, Q., Rehman, R., \& Raoof, A. (2010). Role of corporate governance in firm performance: A comparative study between Chemical and Pharmaceutical sectors of Pakistan. International Research Journal of Finance and Economics, 50, 7-16.

Irina, I., \& Nadezhda, Z. (2009). The relationship between corporate governance and company performance in concentrated ownership systems: The case of Germany. Journal of Corporate Finance, 4(12), 34-56.

Jackling, B., \& Johl, S. (2009). Board structure and firm performance: Evidence from India's top companies. $\begin{array}{lllll}\text { Corporate } \quad \text { Governance: An International } & \text { Review, } & \text { 17(4), }\end{array}$ http://dx.doi.org/10.1111/j.1467-8683.2009.00760.x

Jensen, M. (1993). The modern industrial revolution, exit and the failure of internal control systems. Journal of Finance, 48, 831-880. http://dx.doi.org/10.2307/2329018

Jensen, M., \& Meckling, W. H. (1976). Theory of the firm: managerial behavior, agency costs, and ownership structure. Journal of Financial Economics, 3, 305-360. http://dx.doi.org/10.1016/0304-405X(76)90026-X

Junarsin, E. (2011). Executive compensation and firm performance: An empirical examination. European Journal of Economics, Finance and Administrative Sciences, 28, 163-179.

Kajola, S. O. (2008). Corporate governance and firm performance: The case of Nigerian listed firms. European Journal of Economics, Finance and Administrative Sciences, 14(14), 16-28.

Kang, S., \& Kim, Y. (2011). Does earnings management amplify the association between corporate governance and firm performance? Evidence from Korea. International Business and Economies Research Journal, 10(2), 53-67.

Kazmier, L. (1996). Schaum's Outline of Theory and Problems of Business Statistics. McGraw-Hill, 1996 Business and Economics - 410 pages.

Khan, M., \& Javid, A. (2011). Determinants of board effectiveness: Logit model ferheen kayani. Interdisciplinary Journal of Contemporary Research in Business, 3(2), 1970-1981. 
Khanchel, I. (2007). Corporate governance: Measurement and determinant analysis. Managerial Auditing Journal, 22(8), 740-760. http://dx.doi.org/10.1108/02686900710819625

Kim, H. J., \& Yoon, S. S. (2007). Corporate governance and firm performance in Korea. Malaysian Accounting Review, 6(2), 1-18.

Klein, A. (2002). Audit committee, board of director characteristics, and earnings management. Journal of Accounting and Economics, 33, 375-400. http://dx.doi.org/10.1016/S0165-4101(02)00059-9

Kota, H. M., \& Tomar, C. (2010). Corporate governance practices of Indian firms. Journal of Management and Organization, 16, 266-279. http://dx.doi.org/10.5172/jmo.16.2.266

Koufopoulos, D., Zoumbos, V., Argyropoulou, M., \& Motwani, J. (2008). Top management team and corporate performance: A study of Greek firms. Team Performance Management, 14(8), 340-363. http://dx.doi.org/10.1108/13527590810912322

Kubo, K., \& Saito, T. (2008). The relationship between financial incentives for company presidents and firm performance in Japan. The Japanese Economic Review, 59(4), 401-418. http://dx.doi.org/10.1111/j.1468-5876.2008.00420.x

Kula, V. (2005). The impact of the roles, structure and process of boards on firm performance: Evidence from $\begin{array}{lllll}\text { Turkey. Journal of } & \text { Corporate }\end{array}$ http://dx.doi.org/10.1111/j.1467-8683.2005.00421.x

Kyereboah-Coleman, A., \& Biekpe, N. (2006). The link between corporate governance and performance of the non-traditional export sector: Evidence from Ghana. Corporate Governance Journal, 6(5), 609-623. http://dx.doi.org/10.1108/14720700610706090

Larmou, S., \& Vafeas, Æ. N. (2010). The relation between board size and firm performance in firms with a history of poor operating performance. Journal of Management and Governance, 14, 61-85. http://dx.doi.org/10.1007/s10997-009-9091-z

Lawal, B. (2012). Board dynamics and corporate performance: review of literature, and empirical Challenges. International Journal of Economics and Finance, 4(1), 22-35. http://dx.doi.org/10.5539/ijef.v4n1p22

Lazear, E., \& Rosen, S. (1981). Rank order tournaments as optimum labor contracts. Journal Political Economy, $89,841-864$.

Lee, K. W., Lev, B., \& Yeo, G. H. H. (2008). Executive pay dispersion, corporate governance, and firm performance. Review of Quantitative Finance and Accounting, 30, 315-338. http://dx.doi.org/10.1007/s11156-007-0053-8

Lin, C. (2011). An examination of board and firm performance: evidence from Taiwan. The International Journal of Business and Finance Research, 5(4), 17-35.

Lin, S., \& Hu, S. (2002). A family member or professional management? The choice of a CEO and its impact on performance. Corporate Governance, 15(6), 1348-1363.

Lin, Y., Liao, Y., \& Chang, K. (2011). Firm performance, corporate governance and executive compensation in high-tech businesses. Total Quality Management, 22(2), 159-172.

Lin, Y.-F., Liao, Y.-C., \& Chang, K.-C. (2011). Firm performance, corporate governance and executive compensation in high-tech businesses. Total Quality Management and Business Excellence, 22(2), 159-172. http://dx.doi.org/10.1080/14783363.2010.530786

Lipton, M., \& Lorsch, J. (1992). Modest proposal for improved corporate governance. Business Lawyer, 12(3), 48-59.

Li, J., Kankpang, K., \& Okonkwo, G. (2012). Corporate governance as a driver of organizational efficiency in courier service firms: Empirical findings from Nigeria. Interdisciplinary Journal of Research in Business, 1(1), 26-38.

Mace, M. (1986). Directors: Myth and Reality. Boston: Harvard Business School Press.

Main, B., O'Reilly, C., \& Wade, J. (1993) Top executive pay: tournament or teamwork? J Labor Econ, 11, 606-628.

Makri, M., Lane, P. J., \& Gomez-Mejia, L. R. (2006). CEO incentives, innovation and performance in technology-intensive firms: Behavior-based incentive schemes. Strategy management journal, 27, 1057-1080. http://dx.doi.org/10.1002/smj 
Masood, F. C. (2011). Corporate governance and firm Performance. International Conference on Sociality and Economic Development, 10, 484-489.

Maury, B. (2006). Corporate performance, corporate governance and top executive turnover in Finland. European Financial Management, 12(2), 221-248.

Mayers, D., \& Smith, C. W. (2010). Compensation and board structure: Evidence from Insurance Industry. Journal of Risk and Insurance, 77(2), 297-327.

Mohd, A. M. N. (2011). The effect of implementation of Malaysia code of corporate goverance (MCCG) 2007 on corporate governance attributes and financial performance. Ph.D DPA Dissertation, University Utara Malaysia.

Mohd, M. R., Takiah, M. I., \& Norman, M. S. (2009). Audit committee characteristics in financially distressed and non-distressed companies. Managerial Auditing Journal, 24(7), 624-638. http://dx.doi.org/10.1108/02686900910975350

Mohiuddin, M., \&Karbhari, Y. (2010).Audit committee effectiveness: A critical literature review. AIUB Journal of Business and Economics, 9, 97-125.

MoIlah, A. S., \& Talukdar, M. B. U. (2007). Ownership structure, corporate governance, and firm's performance in emerging markets: Evidence from Bangladesh. The International Journal of Finance, 19(1), 4315-4333.

Muscat Securities Market, MSM Statistics: December 2001, at 30, available at www.msm.gov.om

Najjar, N. (2012). The impact of corporate governance on the insurance firm's performance in Bahrain. International Journal of Learning and Development, 2(2), 1-17.

Nanka-Bruce, D. (2011). Corporate governance mechanisms and firm efficiency. International Journal of Business and Management, 6(5), 28-41. http://dx.doi.org/10.5539/ijbm.v6n5p28

Narjess, B. (2011). Corporate governance and issues from the insurance industry. Journal of Risk and Insurance, 78(3), 501-518. http://dx.doi.org/10.1111/j.1539-6975.2011.01429.x

NazliAnum, M. G. (2010). Ownership structure, corporate governance and corporate performance in Malaysia. International Journal of Commerce and Management, 20(2), 109-119.

NoorAfza, A., \& Ayoib, C. A. (2009). Family Business, Board Dynamics and Firm Value: Evidence from Malaysia. Journal of Financial Reporting \& Accounting, 7(1), 53-74.

Nuryanah, S., \& Islam, S. M. N. (2011). Corporate governance and performance: Evidence from an emerging market. Malaysian Accounting Review, 10(1), 17-42.

O'Connell, V., \& Cramer, N. (2010). The relationship between firm performance and board characteristics in Ireland. European Management Journal, (28), 387-399. http://dx.doi.org/10.1016/j.emj.2009.11.002

Obiyo, O. C., \& Lenee, L. T. (2011). Corporate governance and firm performance in Nigeria. IJEMR, 1(4), 1-12.

Ozkan, N. (2011). CEO compensation and firm performance: An empirical investigation of UK panel data. European Financial Management, 17(2), 260-285.

Pallant, J. F. (2011). SPSS Survival Manual: A step by step guide to data analysis using SPSS (4th ed.). Crows Nest, NSW: Allen \& Unwin.

Pearce, J. H., \& Zahra, S. A. (1992). Board composition from a strategic contingency perspective. Journal of Management Studies, 29(2), 411-438.

Pfeffer, J. (1972). Size, composition, and function of hospital boards of directors. Administrative Science Quarterly, 18(2), 349-364.

Pfeffer, J. (1987). A resource dependence perspective on interorganizational relations. In M. S. Mizruchi, \& M. Schwartz (Eds.), Intercorporate relations: The structural analysis of business (pp. 22-55). Cambridge, UK: Cambridge University Press.

Pfeffer, J., \& Salancik, G. (1978). The external control of organizations: A resource dependence perspective. New York: Harper and Row.

Pfeffer, J., \& Slanick, G. R. (1979). The external control of organizations: a resource dependence perspective. Contemporary Sociology, 8(4), 612-613.

Pissaris, S., Jeffus, W., \& Gleason, K. C. (2010). The joint impact of executive pay disparity and corporate governance on corporate performance. Journal of Managerial Issues, 22(3), 306-329. 
Prabowo, M., \& Simpson, J. (2011). Independent directors and firm performance in family controlled firms: Evidence from Indonesia. Asian-Pacific Economic Literature, 25(1), 121-132. http://dx.doi.org/10.1111/j.1467-8411.2011.01276.x

Premuroso, R. F., \& Bhattacharya, S. (2007). Is there a relationship between firm performance, corporate governance, and a firm's decision to form a technology committee? Corporate Governance, 15(6), $1260-1277$.

Provan, J. (1980). Board power and organizational effectiveness among human service agencies. Academy of Management Journal, 23(2), 221-236. http://dx.doi.org/10.2307/255428

Qinghua, W. U., Pingxin, W., \& Junming, Y. I. N. (2007). Audit committee, board characteristics and quality of financial reporting: An empirical research on Chinese securities market. Front. Bus. Res., 1(3), 385-400. http://dx.doi.org/10.1007/s11782-007-0023-y

Rachdi, H., \& Ameur, I. G. (2011). Board characteristics, performance and risk taking behaviour in Tunisian banks. International Journal of Business and Management, 6(6), 88-98. http://dx.doi.org/10.5539/ijbm.v6n6p88

Rao, N. V., Al-Yahyaee, K. H. M., \& Syed, L. A. M. (2007). Capital structure and financial performance: evidence from Oman. Indian Journal of Economics and Business, 6, 1-14. http://findarticles.com/p/articles/mi_m1TSD/is_1_6/ai_n25012613

Rebeiz, K. S., \& Salameh, Z. (2006). Relationship between governance structure and financial performance in construction. Journal of Management in Engineering, 22(1), 20-26.

Reddy, K., Locke, S., \& Scrimgeour, F. (2010). The efficacy of principle-based corporate governance practices and firm financial performance: An empirical investigation. International Journal of Managerial Finance, 6(3), 190-219. http://dx.doi.org/10.1108/17439131011056224

Rose, C. (2006). Board composition and corporate governance. Eur J Law Econ, 21(2), 113-127. http://dx.doi.org/10.1007/s10657-006-6645-2

Roselina, S. (2001). Examining the effect of leadership structure and CEO tenure on Malaysian property firm performance. Journal of Real Estate Literature, 17(1), 47-63.

Saibaba, M. D., \& Ansari, V. A. (2011). Audit committees and corporate governance: A study of select companies listed in the Indian bourses. The IUP Journal of Accounting Research \& Audit Practices, X(3), 1-10.

Schiehll, E., \& Bellavance, F. (2009). Boards of directors, ceo ownership, and the use of non-financial performance measures in the ceo bonus plan. Corporate Governance: An International Review, 17(1), 90-106. http://dx.doi.org/10.1111/j.1467-8683.2008.00723.x

Shan, Y. G., \& McIver, R. P. (2011). Corporate governance mechanisms and financial performance in China: Panel data evidence on listed non-financial companies. Asia Pacific Business Review, 17(3), 301-324. http://dx.doi.org/10.1080/13602380903522325

Shao, G. (2010). The effects of board structure on media companies' performance: A stakeholder perspective. Journal of Media Business Studies, 7(3), 1-16.

Shaver, D. (2005). Characteristics of corporate boards in single-industry and conglomerate media companies. International Journal of Media Management, 7(3\&4), 112-120.

Shen, W. (2003). The dynamics of the CEO board relationship: an evolutionary perspective. Academy of Management Review, 28, 466-476.

Shivdasani, A., \& Zenner, M. (2002). Best practices in corporate governance: What two decades of research work? New York: Salomon Smith Barney.

Siala, F., Adjaoud, F., \& Mamoghli, C. (2009). The combined effect of external auditor reputation and internal corporate governance on performance. Journal of Academy of Business and Economics, 9(2), 16-29.

Simsek, Z. (2007). CEO tenure and organizational performance : An intervening model. Strategic Management Journal, 28(2), 653-662. http://dx.doi.org/10.1002/smj

Singh, D. A., \& Gaur, A. S. (2009). Business group affiliation, firm governance, and firm performance: Evidence from China and India. Corporate Governance: An International Review, 17(4), 411-425. http://dx.doi.org/10.1111/j.1467-8683.2009.00750.x

Spencer, A. C. (1983). On the edge of the organisation-the role of the outside director. John Wiley. 
Stanwick, P. A., \& Stanwick, S. (2010). The relationship between corporate governance and financial performance: An empirical study of Canadian firms. The Business Review, 16(2), 35-42.

Sueyoshi, T., Goto, M., \& Omi, Y. (2010). Corporate governance and firm performance: Evidence from Japanese manufacturing industries after the lost decade. European Journal of Operational Research, 203(3), 724-736. http://dx.doi.org/10.1016/j.ejor.2009.09.021

Swamy, V. (2011). Corporate governance and firm performance in unlisted family owned firms. Working papers series, 4(2), 37-52.

Switzer, L. N., \& Tang, M. (2009). The impact of corporate governance on the performance of U.S. Small-Cap Firms. International Journal of Business, 14(4), 341-356.

Tsai, W., Hung, J., Kuo, Y., \& Kuo, L. (2006). CEO Tenure in Taiwanese family and nonfamily firms: An Agency. Family business review, XIX(1), 11-28.

Uadiale, O. M. (2010). The impact of board structure on corporate financial performance in Nigeria. International Journal of Business and Management, 5(10), 155-166.

Vafeas, N. (2000). Board structure and the informativeness of earnings. Journal of Accounting and Public Policy, 19(2), 139-166.

Valenti, M. A., Luce, R., \& Mayfield, C. (2011). The effects of firm performance on corporate governance. Management Research Review, 34(3), 266-283. http://dx.doi.org/10.1108/01409171111116295

Wahla, K. U. R., Shah, S. Z. A., \& Hussain, Z. (2012). Impact of ownership structure on firm performance evidence from non-financial listed companies at Karachi stock exchange. International Research Journal of Finance and Economics, (84), 6-13.

Wang, Y., \& Oliver, J. (2009). Board composition and firm performance variance: Australian evidence. Accounting Research Journal, 22(2), 196-212. http://dx.doi.org/10.1108/10309610910987510

Wei, G. (2007). Ownership structure, corporate governance and company performance in China. Asia Pacific Business Review, 13(4), 519-545. http://dx.doi.org/10.1080/13602380701300130

Weisbach, M. S. (1988). Outside directors and CEO turnover. Journal of Financial Economics, 20, 431-461. http://dx.doi.org/10.1016/0304-405X(88)90053-0

Yasser, Q. R., Entebang, H., \& Mansor, S. A. (2011). Corporate governance and firm performance in Pakistan: The case of Karachi Stock Exchange (KSE). Journal of Economic and International Finance, 3(8), 482-491.

Yatim, P. (2010). Board structures and the establishment of a risk management committee by Malaysian listed firms. Journal of Management and Governance, 14(1), 17-36.

Yawson, A. (2006). Evaluating the characteristics of corporate boards associated with layoff decisions. Corporate Governance, 14(2), 75-85.

Zald, M. N. (1967). Urban differentiation, characteristics of board of directors, and organizational effectiveness. American Journal of Sociology, 73, 261-272.

Zubaidah, Z. A., Nurmala, M. K., \& Kamaruzaman, J. (2009). Board structure and corporate performance in Malaysia. International Journal of Economic and Finance, 1(1), 150-164.

\section{Copyrights}

Copyright for this article is retained by the author(s), with first publication rights granted to the journal.

This is an open-access article distributed under the terms and conditions of the Creative Commons Attribution license (http://creativecommons.org/licenses/by/3.0/). 